\title{
PENGARUH INFLASI, TINGKAT SUKU BUNGA, DAN NILAI TUKAR TERHADAP PERTUMBUHAN EKONOMI INDONESIA
}

\author{
Susanto \\ Dosen STIE Bisnis Indonesia, Jakarta
}

\begin{abstract}
The purpose of this study was to determine the effect of inflation, interest rates, and exchange rate on the economic growth of Indonesia in 1996 until 2016. The research method using multiple regression and concept analysis. The results showed partially or simultaneously variable of inflation, interest rate, and exchange rate. The magnitude of this is the result $(R)$ of 0.926 which means showing a very strong relationship / relationship between inflation, interest rates, and exchange rate on the economic growth of Indonesia. The amount of adjusted coefficient of determination (adjusted $\mathrm{R} 2$ ) is 0.831 or $83.1 \%$ which means that independent variables can explain changes in economic growth variables of $83.1 \%$ while the rest of $16.9 \%$ explained by other factors in this study.
\end{abstract}

Keywords: Inflation, Interest Rate, Exchange Rate, Economic Growth

\begin{abstract}
Abstrak : Tujuan dari penelitian ini adalah untuk mengetahui pengaruh inflasi, tingkat suku bunga, dan nilai tukar terhadap pertumbuhan ekonomi Indonesia tahun 1996 sampai dengan tahun 2016. Metode penelitian menggunakan analisis regresi dan korelasi berganda. Hasil penelitian menunjukkan bahwa secara parsial maupun secara simultan variabel inflasi, tingkat suku bunga, dan nilai tukar berpengaruh signifikan terhadap pertumbuhan ekonomi. Besarnya nilai koefisien korelasi (R) sebesar 0,926 yang berarti menunjukkan adanya korelasi/hubungan yang sangat kuat antara inflasi, tingkat suku bunga, dan nilai tukar terhadap pertumbuhan ekonomi Indonesia. Besarnya nilai adjusted coeficient of determination (adjusted $\mathrm{R}^{2}$ ) adalah 0,831 atau $83,1 \%$ yang berarti variabel-variabel bebas dapat menerangkan perubahan pada variabel pertumbuhan ekonomi sebesar 83,1\% sedangkan sisanya sebesar 16,9\% diterangkan oleh faktor-faktor lain diluar penelitian ini.
\end{abstract}

Kata Kunci: Inflasi, Tingkat Suku Bunga, Nilai Tukar, Pertumbuhan Ekonomi 


\section{PENDAHULUAN}

Pada tahun 1997 negara-negara Asia Tenggara di hantam krisis ekonomi, termasuk Indonesia. Krisis finansial Asia Tenggara yang melanda Indonesia pada akhir 1997 dengan cepat berubah menjadi sebuah krisis ekonomi dan politik. Respon pertama Indonesia terhadap masalah ini adalah menaikkan tingkat suku bunga domestik untuk mengendalikan naiknya inflasi dan melemahnya nilai tukar rupiah, dan memperketat kebijakan moneternya. Pada Oktober 1997, Indonesia dan International Monetary Fund (IMF) mencapai kesepakatan tentang program reformasi ekonomi yang diarahkan pada penstabilan ekonomi makro dan penghapusan beberapa kebijakan ekonomi yang dinilai merusak, antara lain Program Permobilan Nasional dan kasus monopoli. Rupiah masih belum stabil dalam jangka waktu yang cukup lama. Krisis ekonomi tidak hanya terjadi pada tahun 1997 yang menghantam negara-negara Asia tetapi pada akhir tahun 2008 ujian lebih besar terjadi, kali ini krisis ekonomi terjadi di seluruh dunia yang lebih dikenal dengan Krisis Global. Sedangkan hubungan dagang antara Indonesia dan Amerika Serikat sangat besar, tentu efeknya juga menjadi lebih sangat besar.

Perencanaan pembangunan ekonomi merupakan sarana utama kearah tercapainya pertumbuhan ekonomi yang tinggi. Dengan perencanaan pembangunan ekonomi suatu negara dapat menentukan serangkaian sasaran ekonomi secara kuantitatif dalam periode tertentu. Melalui perencanaan pembangunan suatu negara dapat memobilisasi sumber daya yang terbatas untuk memperoleh hasil yang optimal dengan lancar, progresif dan seimbang. Menurut teori, saat terjadi krisis dari salah satu negara jelas akan berdampak besar pada perekonomian negara yang menjadi mitra dagangnya. Tampaknya, teori ini tak akan terbukti kalau seluruh masyarakat mempercayai kebijakan yang diambil pemerintah. Sebab, saat krisis tahun 1997 mendera ekonomi nasional, kepercayaan masyarakat terhadap pemerintah dan sistem ekonomi nasional sangat rendah.

Nilai tukar mencerminkan keseimbangan permintaan dan penawaran terhadap mata uang dalam negeri maupun mata uang asing \$US. Merosotnya nilai tukar rupiah merefleksikan menurunnya permintaan masyarakat internasional terhadap mata uang rupiah karena menurunnya peran perekonomian nasional, atau karena meningkatnya permintaan mata uang asing \$US oleh masyarakat karena perannya sebagai alat pembayaran internasional. Kinerja uang khususnya pasar luar negeri diukur melalui kurs rupiah, terutama mata uang dolar AS. Semakin menguat kurs rupiah sampai batas tertentu berarti menggambarkan kinerja di pasar uang semakin menunjukkan perbaikan.

Melemahnya nilai tukar domestik terhadap mata uang asing (seperti Rupiah terhadap US Dolar) memberikan pengaruh yang negatif terhadap pasar ekuitas karena pasar ekuitas menjadi tidak punya daya tarik. Pengamatan nilai mata uang atau kurs sangat penting dilakukan mengingat nilai tukar mata uang sangat berperan dalam pembentukan keuntungan bagi perusahaan. Selain itu pertumbuhan ekonomi merupakan salah satu indikator yang sangat penting dalam menilai kinerja suatu perekonomian, terutama untuk melakukan analisis tentang hasil pembangunan ekonomi yang telah dilaksanakan suatu negara atau suatu daerah. Ekonomi dikatakan mengalami pertumbuhan apabila produksi barang dan jasa meningkat dari tahun sebelumnya. Dengan demikian, pertumbuhan ekonomi menunjukkan sejauh mana aktivitas perekonomian dapat menghasilkan tambahan pendapatan atau kesejahteraan masyarakat pada periode tertentu. Pertumbuhan ekonomi suatu negara atau suatu wilayah yang terus menunjukkan peningkatan, maka itu menggambarkan bahwa perekonomian negara atau wilayah tersebut berkembang dengan baik. 


\section{LANDASAN TEORI}

\subsection{Ekonomi}

Pengertian ekonomi (economy) berasal dari sebuah kata dalam bahasa Yunani yang merujuk kepada "pihak yang mengelola rumah tangga" (Mankiw, 2003:3). Sepintas lalu, pengertian aslinya tersebut terasa kurang jelas. Namun sesungguhnya, antara makna dari istilah "rumah tangga" dan "ekonomi” terdapat begitu banyak kesamaan. Sebuah rumah tangga dihadapkan pada begitu banyak keputusan yang harus diambil. Setiap rumah tangga harus menentukan siapa yang harus mengerjakan apa dan imbalan apa yang pantas diperolehnya. Siapa yang harus memasak? Siapa yang harus mencuci dan menyetrika? Siapa yang boleh memilih saluran televisi yang hendak ditonton? Singkatnya, setiap rumah tangga harus mengalokasikan sumber-sumber dayanya yang langka ke segenap anggotanya, dengan memperhitungkan kemampuan, daya upaya dan keinginan dari setiap anggota keluarga tersebut.

Sedangkan menurut Putong (2002:14) "Ekonomi atau economic dalam banyak literatur ekonomi disebutkan berasal dari bahasa Yunani, yaitu "oikos atau oiku" dan "nomos" yang berarti peraturan rumah tangga. Dengan kata lain, pengertian ekonomi adalah semua yang menyangkut hal-hal yang berhubungan dengan perikehidupan dalam rumah tangga, tentu saja yang dimaksud dan dalam perkembangannya kata rumah tangga bukan hanya sekadar merujuk pada satu keluarga yang terdiri atas suami, istri dan anak-anaknya, melainkan juga rumah tangga yang lebih luas, yaitu rumah tangga bangsa, negara dan dunia.”

\subsection{Teori Makro Ekonomi}

Menurut Putong (2002:145) "Ekonomi Makro merupakan bagian dari ilmu ekonomi yang mengkhususkan mempelajari mekanisme bekerjanya perekonomian secara keseluruhan. Hubungan yang dipelajari dalam ekonomi makro adalah hubungan kausal antara variabel-variabel agregatif (keseluruhan). Di antara variabel-variabel yang dimaksudkan adalah tingkat pendapatan nasional, konsumsi rumah tangga, investasi nasional (pemerintah maupun swasta, tingkat tabungan, belanja pemerintah, tingkat harga-harga umum, jumlah uang beredar, inflasi, tingkat bunga, kesempatan kerja, neraca pembayaran (export dan import), dan lain-lain.”

Perkembangan Teori Makro Ekonomi dalam tahun 1929-1932 terjadi kemunduran ekonomi di seluruh dunia, yang bermula dari kemerosotan ekonomi di Amerika Serikat. Periode itu dinamakan The Great Depression. Pada puncak kemerosotan ekonomi itu, seperempat dari tenaga kerja di Amerika Serikat menganggur dan pendapatan nasionalnya mengalami kemerosotan yang sangat tajam. Kemunduran ekonomi yang serius itu meluas ke seluruh dunia, ke negara-negara industri lain maupun ke negara-negara miskin. Kemunduran ekonomi tersebut menimbulkan kesadaran kepada ahli-ahli ekonomi bahwa mekanisme pasar tidak dapat secara otomatis menimbulkan pertumbuhan ekonomi yang teguh dan tingkat pengguna tenaga kerja penuh. Teori-teori ekonomi sebelumnya juga tidak dapat menerangkan mengapa peristiwa kemunduran ekonomi yang serius tersebut dapat terjadi. Ketidakmampuan tersebut mendorong seorang ahli ekonomi Inggris yang terkemuka pada masa tersebut, yaitu John Maynard Keynes, mengemukakan pandangan dan menulis buku yang pada akhirnya menjadi landasan kepada teori makro ekonomi modern. Pandangan tersebut dikemukakan dalam buku yang berjudul The General Theory of Employment, Interest and Money dan diterbitkan pada tahun 1936.

\subsection{Inflasi}

Putong (2002:254) menyatakan bahwa "Inflasi adalah proses kenaikan harga-harga umum secara terus menerus”. Sedangkan kebalikan dari inflasi adalah deflasi, yaitu penurunan harga secara 
terus menerus, akibatnya daya beli masyarakat bertambah besar, sehingga pada tahap awal barang-barang menjadi langka, akan tetapi pada tahap berikutnya jumlah barang akan semakin banyak karena semakin berkurangnya daya beli masyarakat. Inflasi dapat digolongkan menjadi empat golongan, yaitu inflasi ringan, sedang, berat, dan hiperinflasi. Inflasi ringan terjadi apabila kenaikan harga berada di bawah angka $10 \%$ setahun, inflasi sedang antara $10 \%-30 \%$ setahun, inflasi berat antara 30\%-100\% setahun dan hiperinflasi atau inflasi tak terkendali terjadi apabila kenaikan harga berada di atas $100 \%$.

Angka inflasi dihitung berdasarkan angka indeks yang dikumpulkan dari beberapa macam barang yang diperjual belikan dipasar dengan masing-masing tingkat harga (barangbarang ini tentu saja yang paling banyak dan merupakan kebutuhan pokok/utama bagi masyarakat). Berdasarkan data harga itu disusunlah suatu angka yang di indeks. Angka indeks yang memperhitungkan semua barang yang dibeli oleh konsumen pada masing-masing harganya disebut sebagai indeks harga konsumen (IHK atau consumer price index $=C P I$ ). Berdasarkan indeks harga konsumen dapat dihitung berapa besarnya laju kenaikan harga-harga secara umum dalam periode tertentu. Selain menggunakan IHK, tingkat inflasi juga dapat dihitung dengan menggunakan GNP atau PDB deflator, yaitu membandingkan GNP atau PDB yang diukur berdasarkan harga berlaku (GNP atau PDB nominal) terhadap GNP atau PDB harga konstan (GNP atau PDB riel). Adapun rumus untuk menghitung tingkat inflasi adalah:

$$
\text { In }=\frac{\mathrm{IHK}_{\mathrm{n}}-\mathrm{IHK}_{\mathrm{n}-1}}{\mathrm{IHK}_{\mathrm{n}-1}} \times 100 \% \text { atau In }=\frac{\mathrm{Df}_{\mathrm{n}}-\mathrm{Df}_{\mathrm{n}-1}}{\mathrm{Df}_{\mathrm{n}-1}} \times 100 \%
$$

Keterangan :

In : Inflasi.

$\mathrm{IHK}_{\mathrm{n}} \quad$ : Indeks harga konsumen tahun dasar.

$\mathrm{IHK}_{\mathrm{n}-1}$ : Indeks harga konsumen tahun berikutnya.

$\mathrm{Df}_{\mathrm{n}} \quad$ : GNP atau PDB Deflator tahun berikutnya.

$\mathrm{Df}_{\mathrm{n}-1} \quad$ : GNP atau PDB deflator tahun awal (sebelumnya).

Inflasi dapat menyebabkan gangguan pada stabilitas ekonomi di mana para pelaku ekonomi enggan untuk melakukan spekulasi dalam perekonomian. Di samping itu inflasi juga bisa memperburuk tingkat kesejahteraan masyarakat akibat menurunnya daya beli masyarakat secara umum akibat harga-harga yang naik. Selain itu distribusi pendapatan pun semakin buruk akibat tidak semua orang dapat menyesuaikan diri dengan inflasi yang terjadi. Inflasi memiliki dampak positif dan dampak negatif tergantung parah atau tidaknya inflasi. Apabila inflasi itu ringan, justru mempunyai pengaruh yang positif dalam arti dapat mendorong perekonomian lebih baik, yaitu meningkatkan pendapatan nasional dan membuat orang bergairah untuk bekerja, menabung dan mengadakan investasi. Sebaliknya, dalam masa inflasi yang parah, yaitu pada saat terjadi inflasi tak terkendali (hiperinflasi), keadaan perekonomian menjadi kacau dan perekonomian dirasakan lesu. Orang menjadi tidak bersemangat kerja, menabung, atau mengadakan investasi dan produksi karena harga meningkat dengan cepat. Para penerima pendapatan tetap seperti pegawai negeri atau karyawan swasta serta kaum buruh juga akan kewalahan menanggung dan mengimbangi harga sehingga hidup mereka menjadi semakin merosot dan terpuruk dari waktu ke waktu. Secara umum, inflasi dapat mengakibatkan berkurangnya investasi di suatu negara, mendorong kenaikan suku bunga, mendorong penanaman modal yang bersifat spekulatif, kegagalan pelaksanaan pembangunan, ketidakstabilan ekonomi, defisit neraca pembayaran, dan merosotnya tingkat kehidupan dan kesejahteraan masyarakat. 


\subsection{Tingkat Suku Bunga}

Suku bunga adalah harga dari penggunaan uang atau bisa juga dipandang sebagai sewa atas penggunaan uang untuk jangka waktu tertentu. Atau harga dari meminjam uang untuk menggunakan daya belinya dan biasanya dinyatakan dalam persen (\%). Bagi orang yang meminjam uang, bunga merupakan denda yang harus dibayarkan untuk mengkonsumsi penghasilan sebelum diterima. Bagi orang yang memberikan pinjaman, bunga merupakan imbalan karena menunda konsumsi sekarang hingga waktu dari piutang. Bunga bank dapat diartikan sebagai balas jasa yang diberikan oleh bank yang berdasarkan prinsip konvensional kepada nasabah yang membeli atau menjual produknya. Bunga juga dapat diartikan sebagai harga yang harus dibayar kepada nasabah (yang memiliki simpanan) dengan yang harus dibayar oleh nasabah kepada bank (nasabah yang memperoleh pinjaman), (Kasmir, 2002:121). Dalam kegiatan perbankan sehari-hari ada dua macam bunga yang diberikan nasabahnya yaitu:

1. Bunga Simpanan yaitu bunga yang diberikan sebagai rangsangan atau balas jasa bagi nasabah yang menyimpan uangnya di bank. Bunga simpanan merupakan harga yang harus dibayar bank kepada nasabahnya. Sebagai contoh jasa giro, bunga tabungan dan bunga deposito.

2. Bunga Pinjaman yaitu bunga yang diberikan kepada para peminjam atau harga yang harus dibayar oleh nasabah peminjam kepada bank. Sebagai contoh bunga kredit.

Kedua macam bunga ini merupakan komponen utama faktor biaya dan pendapatan bagi bank. Bunga simpanan merupakan biaya dana yang harus dikeluarkan kepada nasabah sedangkan bunga pinjaman merupakan pendapatan yang diterima dari nasabah. Baik bunga simpanan maupun bunga pinjaman masing-masing saling mempengaruhi satu sama lainnya. Sebagai contoh seandainya bunga simpanan tinggi, maka secara otomatis bunga pinjaman juga terpengaruh ikut naik dan demikian pula sebaliknya. Struktur tingkat bunga di Indonesia yang paling umum didasarkan atas jangka waktu. Tingkat bunga perbankan untuk deposito berjangka dibedakan atas jangka waktu satu bulan, tiga bulan, enam bulan, dua belas bulan dan dua puluh empat bulan, untuk mata uang lokal (rupiah) maupun valuta asing.

Naik turunnya tingkat suku bunga dipengaruhi oleh penawaran dan permintaan uang. Tingkat suku bunga cenderung naik/meningkat apabila permintaan debitur/peminjam lebih besar dari pada jumlah uang atau dana yang ditawarkan kreditur. Sebaliknya, tingkat suku bunga cenderung menurun apabila permintaan debitur lebih kecil daripada jumlah uang atau dana yang ditawarkan kreditur.

\subsection{Teori Mengenai Nilai Tukar (Exchange Rate)}

Perdagangan yang dilakukan antara dua negara tidaklah semudah yang dilakukan dalam satu negara, karena mesti memakai dua mata uang yang berbeda misalnya antara negara Indonesia dan Amerika Serikat, Pengimpor Amerika harus membeli rupiah untuk membeli barang-barang dari Indonesia. Sebaliknya Pengimpor Indonesia harus membeli Dollar Amerika untuk menyelesaikan pembayaran terhadap barang yang dibelinya di Amerika.

Nilai tukar adalah sejumlah uang dari suatu mata uang tertentu yang dapat dipertukarkan dengan satu unit mata uang negara lain. Dalam ekonomi internasional, penting diperhatikan tentang konvertibilitas uang (currency convertibility), yaitu penggunaan mata uang yang dapat dengan mudah ditukarkan dengan mata uang lain yang biasa disebut dengan istilah International Convertible Currency. Penentuan nilai tukar merupakan suatu hal penting bagi perekonomian suatu negara karena hal tersebut merupakan satu alat yang dapat digunakan untuk mendorong 
pertumbuhan ekonomi dan mengisolasi perekonomian suatu negara dari gejolak perekonomian global. Pada dasarnya kebijakan nilai tukar yang ditetapkan suatu negara mempunyai beberapa fungsi utama (Oesman, 1999), yaitu:

1. Untuk mempertahankan keseimbangan neraca pembayaran dengan sasaran akhir menjaga kecukupan cadangan devisa.

2. Untuk menjaga kestabilan pasar domestik.

3. Sebagai instrumen moneter khusus bagi negara yang menerapkan suku bunga dan nilai tukar sebagai sasaran operasional kebijakan moneter.

4. Sebagai nominal anchor dalam pengendalian inflasi.

Persoalan nilai tukar sudah menjadi hal yang sangat penting. Kegiatan pembiayaan ekspor dan impor membutuhkan suatu alat pembayaran yang sah dan berlaku secara internasional, bahkan dapat dikatakan kemampuan dan kondisi perekonomian suatu negara saat ini dapat ditentukan oleh adanya fluktuasi dari nilai tukar tersebut. Selain itu nilai tukar antara mata uang suatu negara terhadap mata uang negara lainnya dapat berubah-ubah atau berfluktuasi. Menurut Salvatore (2008) faktor-faktor yang mempengaruhi nilai tukar tersebut, yaitu:

\section{Relative Prices}

Berhubungan erat dengan tingkat inflasi suatu negara bagi negara yang memiliki tingkat inflasi yang relatif rendah dari negara lainnya, maka mata uang negaranya akan relatif lebih kuat, demikian sebaliknya.

2. Relative Interest Rates

Suatu negara yang memiliki tingkat bunga atau interest rate yang tinggi, maka nilai tukar mata uangnya akan cenderung untuk menguat terhadap mata uang lainnya, karena makin tinggi tingkat suku bunga makin tinggi pula return on investment.

3. Relative Economic Growth Rates

Berhubungan dengan permintaan akan barang dan jasa di suatu negara makin kuat pertumbuhan ekonomi suatu negara, maka nilai mata uangnya cenderung akan melemah. Andaikan pendapatan masyarakat meningkat, maka mereka akan lebih banyak membelanjakan uangnya untuk membeli barang dan jasa. Hal ini tentu saja dapat meningkatkan permintaan akan barang impor akibatnya impor meningkat dan permintaan akan mata uang asing meningkat pula, ini berarti mata uang lokal akan mengalami apresiasi.

4. Current Account Balance

Neraca perdagangan juga dapat mempengaruhi nilai mata uang suatu negara. Apabila impor lebih kecil daripada ekspor berarti permintaan akan mata uang lebih besar, karena kebutuhan tersebut, maka mata uang lokal menjadi terdepresiasi. Demikian sebaliknya, jika nilai impor lebih besar daripada ekspor, maka jumlah penawaran mata uang asing akan meningkat sehingga mata uang lokal akan mengalami apresiasi terhadap mata uang asing tersebut.

\subsection{Pertumbuhan Ekonomi}

Menurut Putong (2002:252) "Pertumbuhan Ekonomi adalah kenaikan pendapatan nasional secara berarti (dengan meningkatnya pendapatan per kapita) dalam suatu periode perhitungan tertentu". Menurut Schumpeter dalam Putong (2002:252) "Pertumbuhan Ekonomi adalah pertambahan output (pendapatan nasional) yang disebabkan oleh pertambahan alami dari tingkat pertambahan penduduk dan tingkat tabungan”. Pertumbuhan ekonomi adalah proses kenaikan output perkapita dalam jangka panjang (Boediono, 1999). Pengertian tersebut mencakup tiga aspek, yaitu: proses, output perkapita dan jangka panjang. Mencerminkan aspek dinamis dari suatu perekonomian 
berkembang atau berubah dari waktu ke waktu. Menurut Sukirno (2013) pertumbuhan ekonomi merupakan suatu alat pengukuran prestasi dari suatu perkembangan perekonomian. Dalam analisis makro ekonomi tingkat pertumbuhan ekonomi yang ingin dicapai suatu Negara diukur dari perkembangan pendapatan nasional riil yang dicapai dalam tahun tertentu.

Produk Domestik Bruto (PDB) adalah pendapatan total dan pengeluaran total nasional atas output barang dan jasa dalam periode tertentu. PDB ini dapat mencerminkan kinerja ekonomi, sehingga semakin tinggi PDB sebuah negara, dapat dikatakan semakin bagus pula kinerja ekonomi di Negara tersebut. Begitu pentingnya peran PDB di dalam suatu perekonomian, maka perlu kiranya untuk menganalisa faktor-faktor apa sajakah yang dapat mempengaruhi PDB. Sebenarnya ada banyak sekali faktor baik secara langsung maupun tidak langsung. Menurut teori Keynes, PDB terbentuk dari empat faktor yang secara positif mempengaruhinya, keempat faktor tersebut adalah konsumsi (C), investasi (I), pengeluaran pemerintah (G), dan ekspor neto (NX). Keempat faktor tersebut kembali dipengaruhi oleh berbagai macam faktor, antara lain dipengaruhi oleh faktor-faktor seperti tingkat pendapatan, tingkat harga, suku bunga, tingkat inflasi, money supply, nilai tukar. Beberapa ekonom berpendapat bahwa kecenderungan menaik bagi output perkapita saja tidak cukup, tetapi kenaikan output harus bersumber dari proses interen perekonomian tersebut. Dengan kata lain proses pertumbuhan ekonomi harus bersifat self generating, yang mengandung arti menghasilkan kekuatan bagi timbulnya kelanjutan pertumbuhan dalam jangka panjang (periode-periode selanjutnya).

\section{METODOLOGI PENELITIAN}

\subsection{Metode Penelitian}

Penelitian ini dibatasi dengan menganalisis data sekunder kuantitatif pada rentang waktu antara tahun 1996-2016 dengan pertimbangan ketersediaan data. Data merupakan segala keterangan atau informasi mengenai hal-hal yang berkaitan dengan tujuan penelitian. Penelitian ini secara keseluruhan menggunakan data sekunder time series. Data sekunder digunakan karena penelitian yang dilakukan meliputi objek yang bersifat makro dan mudah didapat. Data tersebut diolah kembali sesuai dengan kebutuhan model yang digunakan. Sumber data berasal dari berbagai sumber, antara lain Statistik Indonesia terbitan Badan Pusat Statistik, Statistik Ekonomi dan Keuangan Indonesia, Laporan Kebijakan Moneter terbitan Bank Indonesia, dan jurnal-jurnal ilmiah serta literatur-literatur lain yang berkaitan dengan topik penelitian ini. Selain itu, penulis juga melakukan studi literatur untuk mendapatkan teori yang mendukung penelitian. Referensi studi kepustakaan diperoleh melalui jurnal ilmiah dan perpustakaan.

\subsection{Teknik Pengumpulan Data}

Penelitian ini dilakukan menggunakan Penelitian perpustakaan (library research) yaitu kegiatan pengumpulan data yang dilakukan dengan jalan membaca buku atau majalah dan sumber data lainnya didalam perpustakaan atau ditempat lainnya dimana tersimpan buku-buku serta sumbersumber data lainnya. Serta penelitian lapangan (field research) yaitu kegiatan penelitian yang dilakukan dengan jalan mendatangi rumah-rumah, perusahaan-perusahaan, sawah-sawah dan tempat-tempat lainnya yang dijadikan sebagai objek penelitian. Jadi usaha pengumpulan data dilakukan langsung dengan cara menyebarkan kuesioner kepada konsumen yang datang. (Ghozali, 2011). 


\subsection{Teknik Analisis Data}

\subsubsection{Uji Normalitas Data}

Uji normalitas bertujuan untuk menguji apakah dalam model regresi variabel pengganggu atau residual memiliki distribusi normal, seperti diketahui bahwa uji t dan F mengasumsikan bahwa nilai residual mengikuti distribusi normal. Ada dua cara untuk mendeteksi apakah residual berdistribusi normal atau tidak yaitu dengan analisis grafik dan uji statistik (Ghozali, 2011).

\subsubsection{Uji Asumsi Klasik}

\subsubsection{Uji Multikolinearitas}

Uji multikolinearitas digunakan untuk mengetahui apakah terjadi korelasi yang kuat diantara variabel-variabel bebas yang di ikut sertakan dalam pembentukan model. Untuk mendeteksi apakah model regresi linear mengalami multikolinearitas pada masing-masing variabel bebas, maka variabel bebas harus memiliki nilai VIF $>10$. Untuk mendapatkan nilai VIF untuk masingmasing variabel bebas dengan langkah hampir sama dengan mendapatkan nilai Durbin Watson. (Ghozali, 2011).

\subsubsection{Uji Heteroskedastisitas}

Uji heteroskedastisitas bertujuan untuk menguji apakah dalam model regresi terjadi kesamaan variance dari residual suatu pengamatan ke pengamatan lain. Jika variance dari residual suatu pengamatan ke pengamatan lain tetap maka disebut homokedastisitas, dan jika berbeda disebut heteroskedastisitas. Model regresi yang baik adalah yang homokedastisitas atau tidak terjadi heteroskedastisitas. (Ghozali, 2011).

\subsubsection{Uji Autokorelasi}

Uji autokorelasi digunakan untuk menguji apakah dalam sebuah model regresi linear terdapat korelasi antara kesalahan pengganggu pada periode t dengan kesalahan pada periode t-1. Untuk menguji autokorelasi dapat dilihat dari nilai Durbin Watson $(D W)$, yaitu jika nilai $D W$ terletak antara dU dan (4-du) berarti bebas dari autokorelasi. Jika nilai DW lebih kecil dari dL atau DW lebih besar dari (4-dl) berarti terdapat autokorelasi. Nilai dL dan dU dapat dilihat dari tabel Durbin Watson, yaitu nilai $d L ; d U=a ; n ;(k-1)$

\subsubsection{Uji Hipotesis}

Pengujian hipotesis bertujuan untuk menguji apakah terdapat pengaruh variabel bebas terhadap variabel terikat dengan tingkat kesalahan yaitu $\alpha=5 \%$. Dalam penelitian ini metode pengujian hipotesis yang digunakan untuk menganalisis data adalah analisis regresi berganda. Metode ini dipakai untuk menguji pengaruh variabel-variabel bebas terhadap variabel terikat.

\subsubsection{Uji Koefisien Korelasi (Uji R)}

Pengujian ini merupakan pengujian untuk mengetahui ada atau tidaknya hubungan antara variabel bebas dengan variabel terikat, pada pengujian ini dapat dilihat apakah hubungan antara variabel tersebut kuat atau lemah. Menurut Ghozali (2011), dalam menentukan hubungan tersebut dapat dilihat melalui hasil koefisien regresi yaitu antara 0 sampai dengan 1 . Nilai 0 tersebut menunjukkan tidak ada hubungan sedangkan nilai 1 menunjukkan adanya hubungan yang sempurna. Apabila nilai $\mathrm{R}=0,5$ atau $\mathrm{R}>0,5$ maka menunjukkan hubungan yang kuat dan apabila nilai $\mathrm{R}<0,5$ maka menunjukkan hubungan yang lemah. 


\subsubsection{Uji Koefisien Determinasi (Adjusted $\mathbf{R}^{2}$ )}

Pengujian ini untuk mengukur seberapa jauh kemampuan model dalam menerangkan variasi variabel terikat. Dalam pengukuran tersebut dapat dilihat menggunakan nilai $\mathrm{R}^{2}$ dan nilai Adjusted $R^{2}$, akan tetapi banyak peneliti yang menganjurkan untuk menggunakan Adjusted $R^{2}$ dikarenakan penggunaan $\mathrm{R}^{2}$ mempunyai kelemahan mendasar yaitu bisa terhadap jumlah variabel bebas yang dimasukkan kedalam model, setiap tambahan variabel bebas pada model membuat $\mathrm{R}^{2}$ pasti mengalami peningkatan tidak perduli apakah tambahan variabel tersebut berpengaruh secara signifikan terhadap variabel terikat (Ghozali, 2011). Menurut Ghozali (2011) bahwa nilai Adjusted $R^{2}$ berkisar antara 0 sampai dengan 1, apabila Adjusted $R^{2}$ mendekati 1 menunjukkan bahwa hampir semua variabel-variabel bebas yang terdapat dalam model dapat menjelaskan informasi yang dibutuhkan untuk memprediksi variabel terikat.

\subsubsection{Uji t}

Pengujian ini merupakan pengujian yang menunjukkan seberapa jauh pengaruh satu variabel bebas secara individual dalam menerangkan variasi variabel terikat (Ghozali, 2011). Tujuan uji t adalah untuk menguji koefisien regresi secara individual.

Hipotesa $\mathrm{Nol}=\mathrm{H}_{0}$

$\mathrm{H}_{0}$ adalah salah satu pernyataan mengenai nilai parameter populasi. $\mathrm{H}_{0}$ merupakan hipotesis statistik yang akan diuji hipotesis nihil.

$$
\text { Hipotesa alternatif }=\mathrm{H}_{\mathrm{a}}
$$

$\mathrm{H}_{\mathrm{a}}$ adalah satu pernyataan yang diterima jika data sampel memberikan cukup bukti bahwa hipotesa nol adalah salah.

$t=\frac{\mathrm{r} \sqrt{\mathrm{n}-2}}{\sqrt{1}-r^{2}}$

Dimana :

$\mathrm{r}=$ koefisien regresi

$\mathrm{n}=$ jumlah sampel

$\mathrm{t}=\mathrm{uji}$ hipotesis

Kesimpulan :

1. Jika $t_{\text {hitung }} \leq t_{\text {tabel }}$ maka Ha ditolak yang berarti bahwa variabel bebas secara individual berpengaruh terhadap variabel terikat.

2. Jika $t_{\text {hitung }} \geq t_{\text {tabel }}$ maka Ha tidak dapat ditolak yang berarti bahwa variabel bebas secara individual tidak berpengaruh terhadap variabel terikat.

\subsubsection{Uji F}

Pengujian ini merupakan pengujian yang menunjukkan apakah model regresi yang digunakan dalam penelitian adalah model regresi yang baik dan layak dipakai untuk diteliti atau tidak (Ghozali, 2011). Langkah-langkah menguji hipotesa dengan distribusi uji F:

1. Merumuskan Hipotesa

Ho : $\beta_{1}=\beta_{2}=\beta_{3}=0$, berarti secara bersama-sama tidak ada pengaruh variabel bebas terhadap variabel terikat. 
Ha : $\beta_{1} \neq \beta_{2} \neq \beta_{3} \neq 0$, berarti secara bersama-sama ada pengaruh variabel bebas terhadap variabel terikat.

2. Menentukan taraf nyata (level of significance) $=\alpha$

Taraf nyata terdiri dari 3 tingkatan, yaitu:

i. Tingkatan kesatu: $1 \%$

ii. Tingkatan kedua: $5 \%$

iii. Tingkatan ketiga: $10 \%$

Taraf nyata dalam penelitian ini adalah 5\%. Degree of freedom (df) dalam distribusi $\mathrm{F}$ ada dua, yaitu:

$\mathrm{df}$ numerator $=\mathrm{dfn}=\mathrm{df}_{1}=\mathrm{k}-1$

$\mathrm{df}$ denumerator $=\mathrm{dfd}=\mathrm{df}_{2}=\mathrm{n}-\mathrm{k}$

Dimana:

$\mathrm{df}=$ degree of freedom (derajat kebebasan)

$\mathrm{n}=$ jumlah sampel

$\mathrm{k}=$ banyaknya koefisen regresi

3. Menentukan daerah keputusan, yaitu daerah dimana hipotesa nol diterima atau tidak.

Ho diterima apabila $\mathrm{F}_{\text {hitung }} \leq \mathrm{F}_{\text {tabel, }}$ artinya semua variabel bebas secara bersama-sama bukan merupakan variabel penjelas yang signifikan terhadap variabel terikat.

Ho ditolak apabila $F_{\text {hitung }} \geq F_{\text {tabel }}$, artinya semua variabel bebas secara bersama-sama merupakan variabel penjelas yang signifikan terhadap variabel terikat. Keputusan bisa menolak Ho atau menolak Ho bisa menerima Ha, yaitu:

Apabila $\mathrm{F}_{\text {hitung }} \leq \mathrm{F}_{\text {tabel, }}$ maka ditolak sehingga dapat disimpulkan bahwa ada pengaruh yang signifikan antara variabel bebas dengan variabel terikat.

1. Jika tingkat signifikan lebih besar atau sama dengan 5\%, maka model regresi tidak layak digunakan dalam penelitian.

2. Jika tingkat signifikan lebih kecil dari 5\%, maka model regresi layak untuk digunakan dalam penelitian.

\section{ANALISA DAN PEMBAHASAN}

Berdasarkan data pengaruh Inflasi, Tingkat Suku Bunga, dan Nilai Tukar terhadap Pertumbuhan Ekonomi Periode Tahun 1996 sampai dengan 2016, kemudian diolah dengan menggunakan SPSS 19.0, didapat hasil sebagai berikut:

Tabel 4.1. Deskriptif Statistik

\begin{tabular}{|l|r|r|r|r|r|}
\hline \multicolumn{1}{|c|}{ De scriptive Statistics } \\
\hline Inflasi & \multicolumn{1}{|c|}{ N } & Minimum & Maximum & \multicolumn{1}{c|}{ Mean } & Std. Deviation \\
Tingkat_Suku_Bunga & 21 & 2.01 & 77.63 & 10.6119 & 15.80062 \\
Nilai_Tukar & 21 & 5.83 & 37.84 & 11.0600 & 7.11583 \\
Pertumbuhan_Ekonomi & 21 & 3.37 & 4.23 & 3.9694 & .16697 \\
Valid N (listwise) & 21 & .79 & 13.12 & 5.5448 & 2.18588 \\
\hline
\end{tabular}

Berdasarkan tabel 4.1 diatas diketahui bahwa dari 21 sampel variabel Inflasi memiliki nilai minimum sebesar 2,01, nilai maksimum sebesar 77,63, dan dari 21 sampel memiliki nilai 
rata-rata sebesar 10,6119 dan memiliki nilai standar deviasi sebesar 15,80062 yang artinya jika nilai standar deviasi mendekati angka 0 maka data tidak bervariasi, dan sebaliknya jika menjauhi angka 0 atau menjauhi angka 1 maka data bervariasi. Variabel Tingkat Suku Bunga memiliki nilai minimum sebesar 5,83, nilai maksimum sebesar 37,84, dan dari 21 sampel memiliki nilai rata-rata sebesar 11,0600 dan memiliki nilai standar deviasi sebesar 7,11583 yang artinya jika nilai standar deviasi mendekati angka 0 maka data tidak bervariasi, dan sebaliknya jika menjauhi angka 0 atau menjauhi angka 1 maka data bervariasi. Variabel Nilai Tukar memiliki nilai minimum sebesar 3,37, nilai maksimum sebesar 4,23, dan dari 18 sampel memiliki nilai rata-rata sebesar 3,9694 dan memiliki nilai standar deviasi sebesar 0,16697 yang artinya jika nilai standar deviasi mendekati angka 0 maka data tidak bervariasi, dan sebaliknya jika menjauhi angka 0 atau menjauhi angka 1 maka data bervariasi. Variabel Pertumbuhan Ekonomi memiliki nilai minimum sebesar 0,79, nilai maksimum sebesar 13,12, dan dari 21 sampel memiliki nilai rata-rata sebesar 5,5448 dan memiliki nilai standar deviasi sebesar 2,18588 yang artinya jika nilai standar deviasi mendekati angka 0 maka data tidak bervariasi, dan sebaliknya jika menjauhi angka 0 atau menjauhi angka 1 maka data bervariasi.

Sebelum dilakukan analisis untuk mengetahui apakah terdapat pengaruh atau tidaknya Inflasi, Tingkat Suku Bunga, dan Nilai Tukar terhadap Pertumbuhan Ekonomi terlebih dahulu dilakukan pengujian normalitas data dan uji asumsi klasik yang meliputi uji multikolinearitas, uji autokorelasi, dan uji heteroskedastisitas. Berikut ini hasil pengujian normalitas.

\section{Uji Normalitas}

\section{Gambar 4.1 \\ Hasil Uji Normalitas dengan Grafik P-P Plot}

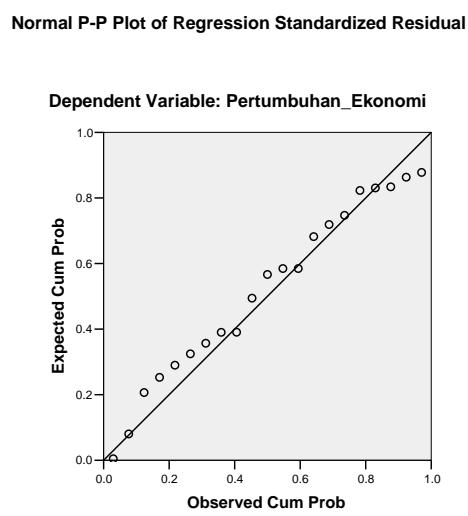

Berdasarkan gambar di atas dapat diketahui bahwa sebaran data mengikuti dan searah garis diagonal, sehingga dapat disimpulkan data terdistribusi normal. Sehingga dapat dilakukan pengujian selanjutnya yaitu pengujian asumsi klasik. Berikut ini hasil pengujian asumsi klasik. 


\section{Uji Asumsi Klasik \\ a. Uji Multikolinearitas}

Tabel 4.2.

Hasil Pengujian Multikolinearitas

\begin{tabular}{|ll|r|c|}
\hline \multicolumn{2}{|c|}{ Coefficients $^{\mathbf{a}}$} \\
\cline { 3 - 4 } Model & \multicolumn{2}{|c|}{ Collinearity Statistics } \\
\cline { 2 - 4 } & & Tolerance & \multicolumn{1}{c|}{ VF } \\
\hline 1 & Inflasi & .134 & 7.436 \\
& Tingkat_Suku_Bunga & .149 & 6.712 \\
& Nilai_Tukar & .721 & 1.387 \\
\hline
\end{tabular}

a. Dependent Variable: Pertumbuhan_Ekonomi

Berdasarkan tabel di atas diketahui nilai tolerance yang mendekati angka 1 dan nilai VIF (Variance Inflation Factor) yang berada dibawah nilai 10 sehingga dapat disimpulkan bahwa tidak terjadi multikolinearitas artinya tidak terjadinya korelasi/hubungan diantara variabel bebas. Sehingga pengujian selanjutnya dapat dilanjutkan, karena telah memenuhi syarat pengujian asumsi klasik yang pertama yaitu tidak terjadinya multikolinearitas. Berikut ini merupakan hasil pengujian autokorelasi.

\section{b. Uji Autokorelasi}

Gambar 4.2

\section{Hasil Pengujian Autokorelasi}

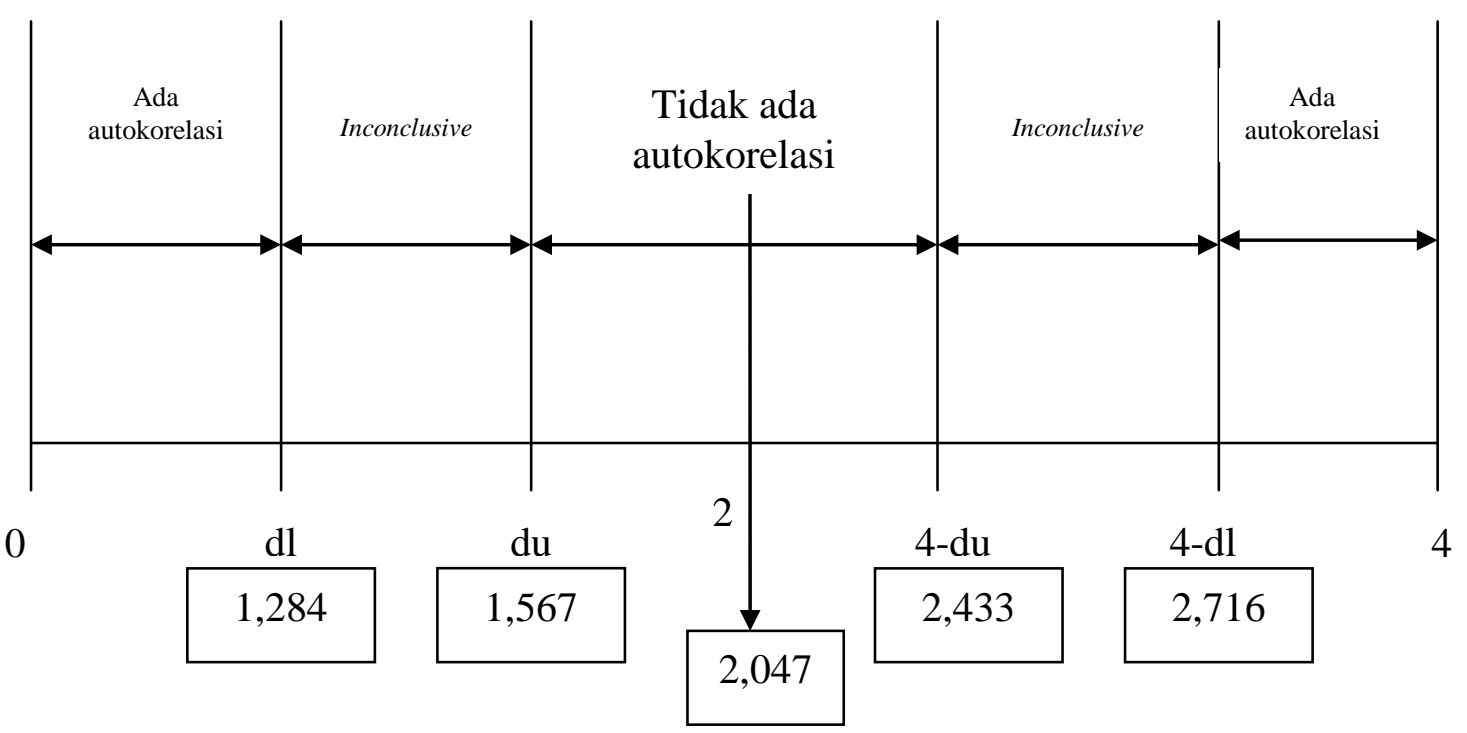

Berdasarkan gambar pengujian autokorelasi diatas nilai Durbin-Watson berada diantara nilai du $\leq$ DW $\leq$ 4-du sehingga dapat disimpulkan tidak terjadi autokorelasi. Sehingga dapat dilanjutkan kepada uji heteroskedastisitas. Berikut ini hasil pengujian ada atau tidaknya heteroskedastisitas dalam model yang dibuat. 


\section{c. Uji Heteroskedastisitas}

Berdasarkan hasil pengolahan data Uji Heteroskedastisitas dapat dilihat pada tabel dibawah ini:

Gambar 4.3.

Hasil Uji Heteroskedastisitas dengan Scatterplot

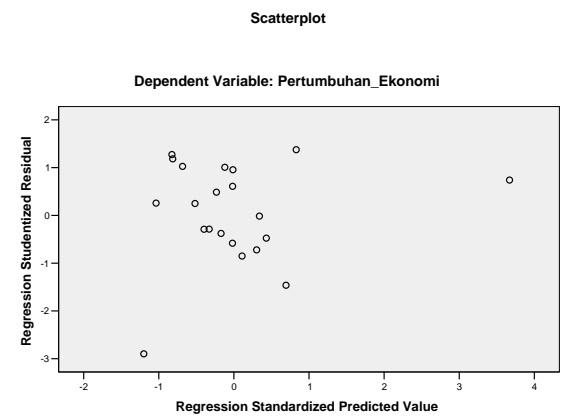

Dari gambar 4.3 di atas terlihat bahwa titik-titik menyebar secara acak serta tersebar baik di atas maupun di bawah angka 0 pada sumbu Y. Hal ini dapat disimpulkan bahwa tidak terjadi heteroskedastisitas pada model regresi, sehingga model regresi layak dipakai untuk memprediksi Pertumbuhan Ekonomi berdasarkan masukkan variabel bebas Inflasi, Tingkat Suku Bunga, dan Nilai Tukar.

\section{Uji Koefisien Determinasi $\left(\mathbf{R}^{2}\right)$}

Tabel 4.3

\section{Hasil Uji Koefisien Determinasi}

Model Summary

\begin{tabular}{|l|r|r|r|r|}
\hline Model & \multicolumn{1}{|c|}{ R } & R Square & $\begin{array}{c}\text { Adjusted } \\
\text { R Square }\end{array}$ & $\begin{array}{c}\text { Std. Error of } \\
\text { the Estimate }\end{array}$ \\
\hline 1 & $.926^{\mathrm{a}}$ & .857 & .831 & .89751 \\
\hline
\end{tabular}

a. Predictors: (Constant), Nilai_Tukar, Tingkat_Suku_ Bunga, Inflasi

b. Dependent Variable: Pertumbuhan_Ekonomi

Berdasarkan tabel 4.3 di atas diketahui nilai R sebesar 0,926 artinya variabel Inflasi, Tingkat Suku Bunga dan Nilai Tukar memiliki hubungan yang sangat kuat dengan variabel Pertumbuhan Ekonomi. Sedangkan nilai adjusted $\mathrm{R}^{2}$ sebesar 0,831 atau sebesar 83,1\% artinya besar kontribusi pengaruh dari variabel Inflasi, Tingkat Suku Bunga, dan Nilai Tukar terhadap Pertumbuhan Ekonomi sebesar 83,1\% sedangkan sisanya sebesar 15,9\% dipengaruhi oleh variabel lain yang tidak dimasukkan dalam model.

\section{Uji F (Pengujian Simultan)}

Digunakan untuk menguji apakah secara bersama-sama seluruh variabel bebas mempunyai pengaruh yang signifikan terhadap variabel terikat. Dasar pengambilan keputusan untuk pengujian secara simultan ini adalah dengan membandingkan $p$-value dengan nilai alpha sebesar 
0,05. Jika $p$-value < alpha 0,05 maka Ho ditolak dan sebaliknya jika $p$-value $>$ alpha 0,05 maka Ho diterima.

Tabel 4.4.

Hasil Uji F

ANOV A

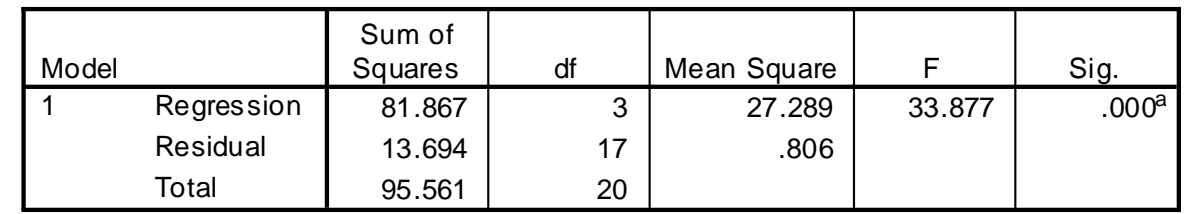

a. Predictors: (Constant), Nilai_Tukar, Tingkat_Suku_Bunga, Inflasi

b. Dependent Variable: Pertumbuhan_Ekonomi

Berdasarkan tabel 4.4 di atas diketahui nilai $F_{\text {hitung }}>F_{\text {tabel }}$ atau 33,877 $>2,930$ dan nilai signifikansi $<0,05$ atau 0,000 $<0,05$ sehingga dapat disimpulkan secara bersama-sama Inflasi, Tingkat Suku Bunga, dan Nilai Tukar mempengaruhi Pertumbuhan Ekonomi.

\section{Uji t (Pengujian Secara Parsial)}

Untuk menguji koefisien regresi dilakukan pengujian secara parsial untuk melihat signifikansi dari pengaruh masing-masing variabel bebas terhadap variabel terikat dengan mengasumsikan variabel lain adalah konstan. Dasar pengambilan keputusan untuk pengujian secara parsial ini adalah dengan membandingkan $p$-value dengan nilai alpha sebesar 0,05. Jika $p$-value $<$ alpha 0,05 maka Ho ditolak dan sebaliknya jika $p$-value > alpha 0,05 maka Ho diterima.

Tabel 4.5.

Hasil Uji t

Coefficients ${ }^{a}$

\begin{tabular}{|c|c|c|c|c|c|c|}
\hline \multirow{2}{*}{\multicolumn{2}{|c|}{ Model }} & \multicolumn{2}{|c|}{$\begin{array}{c}\text { Unstandardized } \\
\text { Coefficients }\end{array}$} & \multirow{2}{*}{$\begin{array}{c}\text { Standardized } \\
\text { Coefficients }\end{array}$} & \multirow[b]{2}{*}{$\mathrm{t}$} & \multirow[b]{2}{*}{ Sig. } \\
\hline & & B & Std. Error & & & \\
\hline & (Constant) & 27.996 & 5.801 & & 4.826 & .000 \\
\hline & Inflasi & .273 & .035 & 1.970 & 7.870 & .000 \\
\hline & Tingkat_Suku_Bunga & -.353 & .073 & -1.150 & -4.835 & .000 \\
\hline & Nilai_Tukar & -5.401 & 1.416 & -.413 & -3.815 & .001 \\
\hline
\end{tabular}

a. Dependent Variable: Pertumbuhan_Ekonomi

Berdasarkan tabel 4.5 di atas:

\section{Hipotesis 1}

\section{Pengaruh Inflasi terhadap Pertumbuhan Ekonomi}

Ho : Tidak terdapat pengaruh antara Inflasi terhadap Pertumbuhan Ekonomi.

$\mathrm{Ha}_{1}$ : Terdapat pengaruh antara Inflasi terhadap Pertumbuhan Ekonomi.

Dari pengujian regresi dengan melihat tabel Coefficients, diketahui p-value untuk hipotesa 1 adalah $0,000<$ alpha 0,05 dan $\mathrm{t}_{\text {hitung }}>\mathrm{t}_{\text {tabel }}$ atau 7,870 $>1,699$ maka Ho ditolak. Artinya terdapat pengaruh secara signifikan antara Inflasi terhadap Pertumbuhan Ekonomi. 


\section{Hipotesis 2 \\ Pengaruh Tingkat Suku Bunga terhadap Pertumbuhan Ekonomi}

Ho : Tidak terdapat pengaruh antara Tingkat Suku Bunga terhadap Pertumbuhan Ekonomi.

Ha2 : Terdapat pengaruh antara Tingkat Suku Bunga terhadap Pertumbuhan Ekonomi.

Dari pengujian regresi dengan melihat tabel Coefficients, diketahui p-value untuk hipotesa 2 adalah $0,000<$ alpha 0,05 dan $t_{\text {hitung }}>t_{\text {tabel }}$ atau $-4,835<-1,699$, maka Ho ditolak. Artinya terdapat pengaruh secara signifikan antara Tingkat Suku Bunga terhadap Pertumbuhan Ekonomi.

\section{Hipotesis 3}

\section{Pengaruh Nilai Tukar terhadap Pertumbuhan Ekonomi}

Ho : Tidak terdapat pengaruh antara Nilai Tukar terhadap Pertumbuhan Ekonomi.

$\mathrm{Ha}_{3}$ : Terdapat pengaruh antara Nilai Tukar terhadap Pertumbuhan Ekonomi.

Dari pengujian regresi dengan melihat tabel Coefficients, diketahui p-value untuk hipotesa 3 adalah $0,001<$ alpha 0,05 dan $t_{\text {hitung }}>t_{\text {tabel }}$ atau -3,815 $<-1,699$, maka Ho ditolak. Artinya terdapat pengaruh secara signifikan antara Nilai Tukar terhadap Pertumbuhan Ekonomi.

\section{SIMPULAN DAN SARAN}

\subsection{Simpulan}

Berdasarkan hasil pembahasan pada bab sebelumnya, maka dapat disimpulkan:

1. Terdapat pengaruh secara signifikan antara Inflasi terhadap Pertumbuhan Ekonomi atau Ho ditolak dan Ha diterima.

2. Terdapat pengaruh secara signifikan antara Tingkat Suku Bunga terhadap Pertumbuhan Ekonomi atau Ho ditolak dan Ha diterima.

3. Tidak terdapat pengaruh secara signifikan antara Nilai Tukar terhadap Pertumbuhan Ekonomi atau Ho ditolak dan Ha diterima.

4. Terdapat pengaruh secara bersama-sama antara Inflasi, Tingkat Suku Bunga dan Nilai Tukar terhadap Pertumbuhan Ekonomi atau Ho ditolak dan Ha. diterima.

\subsection{Saran}

Adapun saran-saran yang dapat diberikan oleh penulis, yaitu:

1. Untuk menarik para investor maka pemerintah harus mampu menciptakan iklim investasi yang kondusif melalui penegakan supermasi hukum, peningkatan kinerja kelembagaan dan adanya undang-undang investasi yang sesuai dengan kebutuhan pasar.

2. Tingkat inflasi perlu diperhatikan agar tidak terlalu tinggi dan tidak terlalu rendah. Sebab inflasi akan berdampak langsung terhadap pertumbuhan ekonomi.

3. Pemerintah dan Bank Indonesia diharapkan dapat bekerja sama dalam memberikan kebijakan dengan memperhatikan segala aspek yang ada baik eksternal maupun internal sehingga masyarakat merasa aman dan tenang dalam melakukan kegiatan perekonomian.

4. Penelitian ini sebaiknya dilanjutkan dengan melihat apakah hubungan faktor lain pengaruh ekspor, impor, tingkat pengangguran, tingkat pendapatan, dan lainnya dapat memperkirakan pertumbuhan ekonomi. Selain itu, masih perlu dilakukan penelitian dengan metode statistik yang berbeda yang mungkin lebih baik seiring dengan perkembangan ilmu ekonomi yang lebih baik. 


\section{DAFTAR PUSTAKA}

Boediono. 1999. Ekonomi Moneter, Seri Sinopsis Pengantar Ilmu Ekonomi Moneter No. 5, Edisi Ketiga. Penerbit BPFE. Yogyakarta.

Ghozali, Imam. 2011. Aplikasi Analisis Multivariate dengan Program SPSS. Badan Penerbit Universitas Diponegoro. Semarang.

Kasmir. 2002. Bank dan Lembaga Keuangan Lainnya. Edisi Revisi 2002. Penerbit PT. Raja Grafindo Persada. Jakarta.

Kuncoro, M. 2000. Desentralisasi Fiskal Di Indonesia : Dilema Otonomi Dan Ketergantungan. Prisma 4 : $3-17$.

Mankiw. N. George. 2003. Teori Makro Ekonomi Edisi Kelima Seri Bahasa Indonesia. Penerbit Erlangga. Jakarta.

Oesman, Helma. 1999. Penerapan Kebijakan Nilai Tukar di Indonesia. Jurnal Ilmu dan Budaya. Vol. 12. Jakarta.

Pratiwi, Tara Eka dan Santosa, Purbayu Budi. 2012. Analisis Perilaku Kurs Rupiah (IDR) Terhadap Dollar Amerika (USD) Pada Sistem Kurs Mengambang Bebas Di Indonesia Periode 1997.3 - 2011.4 (Aplikasi Pendekatan Keynesian Sticky Price Model). Diponegoro Journal of Economics. Volume I, Nomor1. Tahun 2012. Fakultas Ekonomika dan Bisnis Universitas Diponegoro.

Puspaningrum, Roshinta. Suhadak. dan Zahroh ZA. 2014. Pengaruh Tingkat Inflasi, Tingkat Suku Bunga SBI, dan Pertumbuhan Ekonomi Terhadap Nilai Tukar Rupiah, Studi Pada Bank Indonesia Periode Tahun 2003-2012. Jurnal Administrasi Bisnis (JAB). Vol. 8 No. 1. Fakultas Ilmu Administrasi. Universitas Brawijaya. Malang.

Putong, Iskandar. 2002. Pengantar Ekonomi Mikro dan Makro, Penerbit Ghalia Indonesia. Jakarta.

Putra, Eka Dianata. 2002 Berburu Di Pasar Modal, Edisi 1, Ephar dan Dahara Prize, Jakarta.

Rahardja, Pratama dan Manurung, Mandala, 2014. Teori Ekonomi Makro: Suatu Pengantar. Edisi Kelima, Lembaga Penerbit Fakultas Ekonomi Universitas Indonesia. Jakarta.

Salvatore, Dominick. 2008. Theory and Problem of Micro Economic Theory. $3{ }^{\text {rd }}$ Edition. Alih Bahasa oleh Rudi Sitompul. Penerbit Erlangga. Jakarta.

Samuelson, Paul A dan Nordhaus, William, D. 2001. Makro-Ekonomi, Edisi Keempat Belas. Penerbit Erlangga. Jakarta.

Sugiyono. 2004. Metode Penelitian Administrasi, Penerbit Alfabetha. Bandung.

Sukirno, Sadono. 2013. Makro Ekonomi: Teori Pengantar. Edisi Ketiga. Penerbit Rajawali Pers. Jakarta.

Triyono. 2008. Analisis Perubahan Kurs Rupiah Terhadap Dollar Amerika. Jurnal Ekonomi Pembangunan. Vol. 9, No. 2, Desember 2008, hal. 156 - 167. Fakultas Ekonomi Universitas Muhammmadiyah. Surakarta.

Tambunan, Tulus. 2001. Perekonomian Indonesia: Teori dan Temuan Empiris. Penerbit Ghalia Indonesia. Jakarta.

Wibowo, Tri dan Amir, Hidayat. 2005. Fakor-Faktor Yang Mempengaruhi Nilai Tukar Rupiah. Jurnal Kajian Ekonomi dan Keuangan, Departemen Keuangan. Vol. 9 No. 4, Desember 2005.

Yuliadi, Imamudin. 2008. Ekonomi Moneter. PT. Indeks. Jakarta. 